\title{
Hexazinone site preparation improves black spruce seedling survival and growth
}

\author{
by Phillip E. Reynolds ${ }^{1}$ and Michael J. Roden
}

Granular (PRONONE 10G and 5G) and liquid (VELPAR L) hexazinone (1 to $4 \mathrm{~kg}$ ai ha- ${ }^{-1}$ ) were applied to a northern New Brunswick clearcut (loams, silt loams, and clay loams) to reduce raspberry [Rubus idaeus L. var. strigosus (Michx.) Maxim] competition. Treatment, using skidder-mounted herbicide application equipment, was completed in May and September 1986, with planting of $2+2$, bareroot, black spruce seedlings [Picea mariana (Mill.) B.S.P.] in June 1986 and in June 1987. Seedling survival and growth were measured yearly for five growing seasons after planting. By August 1991, raspberry cover for three treatments remained less than that for controls. Survival of seedlings planted approximately one month after spring treatment was less than controls, but seedling height and stem diameter were greater than that of control seedlings for most treatments. Survival and growth of seedlings planted approximately one year after spring treatment or nine months after fall treatment were greater than that of control seedlings for most treatments. Fifth-year height and stem diameter of seedlings planted nine months after fall treatment were negatively correlated with raspberry height $\left(r^{2}=\right.$ 0.729 , height and 0.745 , diameter), decreasing as raspberry height increased. Over the five-year observation period, hexazinone formulation did not affect raspberry control, but did affect seedling survival and growth. Spring treatment with PRONONE $10 \mathrm{G}\left(2 \mathrm{~kg}\right.$ ai ha $\left.{ }^{-1}\right)$, with planting delayed by one year, provided the best treatment to achieve both optimal seedling survival and growth during plantation establishment.

Key words: liquid hexazinone, granular hexazinone, site preparation, black spruce, growth parameters, seedling survival, raspberry competition
De l'hexazinone granulaire (PRONONE $10 \mathrm{G}$ et $5 \mathrm{G}$ ) et liquide (VELPAR L) (1 à $4 \mathrm{~kg}$ ia ha $\left.^{-1}\right)$ a été répandu sur une coupe à blanc située dans le nord du Nouveau-Brunswick (loams, loams silteux et loams argileux) dans le but de réduire la compétition exercée par les framboisiers [Rubus idaeus L. var. strigosus (Michx.) Maxim]. Le traitement effectué au moyen d'équipement d'épandage de phytocide monté sur un débardeur, a été réalisé en mai et septembre 1986, suivi de la plantation de semis à racines nues $2+2$ d'épinette noire [Picea mariana (Mill.) B.S.P.] en juin 1986 et juin 1987. Le taux de survie et la croissance des semis ont été mesurés à chaque année au cours des cinq années qui ont suivi la plantation. Au cours du mois d'août 1991, le couvert de framboisiers suite aux trois traitements était moindre que sur le site témoin. La survie des semis plantés approximativement un mois après le traitement effectué au printemps était inférieure aux semis témoins, mais la hauteur et le diamètre de la tige des semis étaient supérieurs aux semis témoins pour la plupart des traitements. La survie et la croissance des semis plantés approximativement un an après le traitement effectué au printemps ou neuf mois après le traitement réalisé à l'automne étaient supérieurs aux semis témoins dans la plupart des cas. Cinquantequatre mesures de la hauteur et du diamètre de la tige des semis plantés neuf mois après le traitement réalisé à l'automne ont été corrélées négativement en fonction de la hauteur des framboisiers ( $r^{2}=0.729$, hauteur et 0.745 , diamètre); les valeurs diminuaient avec l'augmentation de la hauteur des framboisiers. Au cours de la période d'observation de cinq ans, la formulation de l'hexazinone n'a pas eu d'impact sur le contrôle des framboisiers, mais a affecté le taux de survie et la croissance des semis. L'application effectuée au printemps de PRONONE 10G (2 kg ia $\mathrm{ha}^{-1}$ ), suivie d'une plantation réalisée un an plus tard, a constitué le meilleur traitement qui a permis d'atteindre à la fois un niveau optimal de survie et de croissance des semis au cours de la période d'établissement des plantations.

Mots clés: hexazinone liquide, hexazinone granulaire, préparation de terrain, épinette noire, paramètres de croissance, survie des semis, compétition des framboisiers

\section{Introduction}

Red raspberry [Rubus idaeus L. var. strigosus (Michx.) Maxim.] is often the dominant competitor threatening the establishment of spruce plantations in eastern Canada and in northeastern Maine (Reynolds 1988). Presently, few herbicides effective in controlling raspberry competition are registered for forestry use in Canada. Glyphosate (VISION), a conifer release herbicide, is the primary herbicide used to reduce raspberry competition (Campbell 1990). Two site preparation herbicide products that also provide effective raspberry control are registered for silvicultural use in Canada. They include the liquid (VELPAR L) and granular (PRONONE) formulations of hexazinone.

This work reports raspberry control through five or six seasons after spring and fall site preparation with granular

Forest Pest Management Institute, Natural Resources Canada, 1219 Queen St. East, Sault Ste. Marie, Ontario, Canada P6A 5M7.

${ }^{1}$ Author to whom all correspondence should be addressed.
(PRONONE 10G and 5G) and liquid (VELPAR L) hexazinone formulations and survival and growth of black spruce [Picea mariana (Mill.) B.S.P.] seedlings through five growing seasons after planting. Evaluations of PRONONE and VELPAR L efficacy during the first or second growing seasons after treatment demonstrated that both formulations are effective in controlling raspberry (Reynolds et al. 1988, 1989a). Seedling mortality increased through August 1989 for all treatments, but was highest for seedlings planted one month after spring treatment in May 1986 (Reynolds et al. 1989b, Reynolds and Roden 1991b). The number of seedlings overtopped by raspberries declined through time, and differences in overtopping between treated and control seedlings were generally significant (Reynolds and Roden 1991a). By August 1989, the number of seedlings planted into spring hexazinone treatments, and taller than surrounding raspberries, ranged from 82 to $97 \%$ compared with $31 \%$ for control seedlings; seedlings planted nine months after fall treatments in September 1986, and taller than surrounding 
raspberries, ranged from 90 to 95\% (Reynolds and Roden 1991a). Overtopped seedlings generally exhibited poor growth morphology (i.e. tall, thin and twisted stems), were characterized by chlorotic or numerous brown needles, and frequently suffered extensive needle loss. In 1989, the health of seedlings taller than surrounding raspberries was better than that of overtopped seedlings.

Objectives of this study were: (1) to quantify development of raspberry cover and height on untreated control plots and after hexazinone treatment, (2) to investigate survival and growth of bareroot, black spruce seedlings planted at different time intervals after spring or fall site preparation with different formulations of hexazinone, and (3) to determine the optimum time of treatment, formulation, and rate to achieve maximum seedling survival and growth during the plantation establishment phase.

\section{Methods}

\section{Site and Experimental Design}

The clearcut treatment area was a J.D. Irving, Ltd. property near St. Leonard (approximately $47^{\circ} 17^{\prime}$ latitude and $67^{\circ} 43^{\prime}$ longitude), in northwest New Brunswick at approximately 240 $\mathrm{m}$ elevation. Soils were fine-textured, including loams, silty loams, clay loams, silty clays, and clays. Mean sand, silt, and clay contents were $29.7,44.3$, and $26.0 \%$, respectively. The duff layer varied from 3 to $11 \mathrm{~cm}$, organic matter from 2.4 to 25.5\%, CEC from 6.2 to $18.9 \mathrm{meq} 100 \mathrm{~g}^{-1}$, and $\mathrm{pH}$ from 3.6 to 4.9. Annual precipitation averaged $108 \mathrm{~cm}$, falling mostly as rain between May and October. Approximately 7, 5, 14, 18,11 , and $5 \mathrm{~cm}$ of rain was received each month, respectively, from May through October 1986. Soil freezing occurred in early November 1986.

The site was clearcut in the fall of 1984 and mechanically site prepared in the summer of 1985, using a 125-ton Letourneau crusher to fell snags and break up residual logging slash. Prior to being harvested, the stand consisted of approximately $45 \%$ balsam fir [Abies balsamea (L.) Mill.], 35\% black spruce, and 20\% hardwoods composed primarily of aspen (Populus tremuloides Michx.) and a variety of other northern hardwoods. Following site preparation, portions of the site not treated with hexazinone, rapidly revegetated with a dense cover of raspberries.
All treatments were replicated four times. Treatment plots were randomly assigned. No significant differences in soil characteristics (i.e. pH, organic matter, CEC, $\%$ sand, $\%$ silt, \% clay) were observed among treatments. Treatment plots $(0.5 \mathrm{ha})$ were separated by $25 \mathrm{~m}$ buffers.

\section{Treatments and Planting}

Ten per cent granular hexazinone (PRONONE 10G, 1, 2, and $4 \mathrm{~kg}$ ai ha $^{-1}$ ) and $5 \%$ granular hexazinone (PRONONE 5G, $2 \mathrm{~kg}$ ai ha ${ }^{-1}$ ) were applied on 27 May 1986 using a skidder fitted with a hydraulic blower unit (OMNI system) designed for application of granular herbicides. Liquid hexazinone (VELPAR L, $2 \mathrm{~kg}$ ai ha- ${ }^{-1}$ ) was applied in $364 \mathrm{~L} \mathrm{ha}^{-1}$ water on 29 May 1986 using a skidder-mounted hydraulic sprayer, equipped with a cluster nozzle. PRONONE 10G ( $2 \mathrm{~kg}$ ai ha- $\left.{ }^{-1}\right)$ and VELPAR $\mathrm{L}\left(2 \mathrm{~kg}\right.$ ai ha $\left.{ }^{-1}, 436 \mathrm{~L} \mathrm{ha}^{-1}\right)$ were applied on 18 September 1986 using the same skidder-mounted application equipment.

Controls and half of each spring hexazinone plot (split-plot design) were planted (2.1 m spacing) in June 1986 and in June 1987 with local, 2+2, bareroot black spruce seedlings obtained from the Irving nursery. Fall hexazinone plots were planted in June 1987 with the same bareroot stock. A total of 480 (i.e. 80 per treatment) seedlings planted in 1986 and 640 seedlings planted in 1987 were randomly selected and staked for yearly measurement.

\section{Measurements and Analysis}

Seedling survival $(\%)$, height $(\mathrm{cm})$, and basal stem diameter $(\mathrm{mm})$ were measured annually (August). Cover (\%) of the dominant competitor, raspberry, was estimated visually within a $1 \mathrm{~m}$ radius of each staked seedling to the nearest $5 \%$ value. The height of raspberry stems within each quadrant of the circle was measured to the nearest centimetre.

Analyses of variance (ANOVA's) were performed on black spruce seedling growth and raspberry competition data. Treatment means were compared by Tukey's Studentized Range (HSD) Test at 5\% level of significance. Orthogonal contrasts of liquid vs. granular hexazinone $\left(2 \mathrm{~kg}\right.$ ai ha $\left.{ }^{-1}\right)$ treatments were performed to establish differences in performance due to formulation. The frequency of occurrence of live seedlings was compared with a Likelihood Ratio Chi-Squared (G-

Table 1. Mean raspberry cover (\%) and height (cm) in August 1990 and in August 1991 for spring and fall treatments

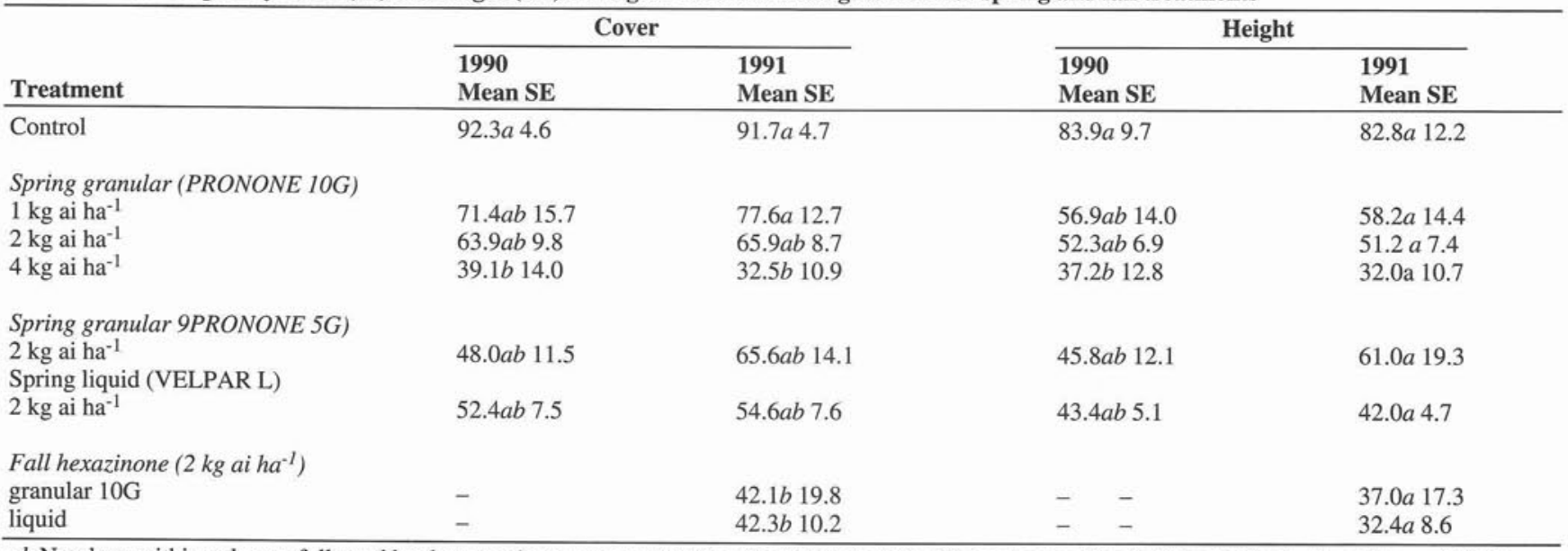

$a b$ Numbers within columns followed by the same letter are not significantly different at the 5\% level according to Tukey's Studentized Range (HSD) Test. 
Table 2. Survival (\%) five growing seasons after planting, of bareroot black spruce seedlings planted after spring or fall site preparation with liquid and granular hexazinone formulations

\begin{tabular}{|c|c|c|c|}
\hline \multirow[b]{2}{*}{ Treatment } & \multicolumn{2}{|c|}{ Spring treatment } & \multirow{2}{*}{$\begin{array}{l}\text { Fall treatment } \\
\text { Planted June } 1987\end{array}$} \\
\hline & Planted June 1986 & Planted June 1987 & \\
\hline Control & $86.4 a$ & $67.2 b$ & $67.2 b$ \\
\hline $\begin{array}{l}\text { Liquid (VELPAR L) } \\
2 \mathrm{~kg} \text { ai } \mathrm{ha}^{-1}\end{array}$ & $82.5 a$ & $76.0 a$ & $69.5 a$ \\
\hline
\end{tabular}

$a, b$ Numbers within columns followed by the same letter are not significantly different at the $5 \%$ level according to G-Squared Test.

Squared) Test (Sokal and Rohlf 1981). Regression analyses were performed on fifth-year seedling growth vs. raspberry cover or height. Where slopes were judged to be statistically significant, analyses of covariance (ANCOVA) were performed to establish significant treatment differences due to planting time, application time, or formulation.

\section{Results}

By August 1991 (i.e. six growing seasons after treatment [GSAT]), mean raspberry cover had increased to $92 \%$ in untreated plots (Table 1), and was greater than in spring plots $(P=0.008)$ treated with granular hexazinone at $4 \mathrm{~kg}$ ai $\mathrm{ha}^{-1}(32 \%)$ or in fall (i.e. 5 GSAT) plots $(P=0.013)$ treated with liquid or granular hexazinone at $2 \mathrm{~kg}$ ai ha ${ }^{-1}(42 \%)$ each. No treatment difference in raspberry height was observed in 1991. No differences in raspberry control (cover or height), attributable to formulation (5\% granular vs. 10\% granular vs. liquid) were observed throughout this study.

Survival of seedlings planted approximately one month after spring treatment was less than controls (Table 2). Survival of seedlings planted approximately one year after spring treatment or nine months after fall treatment was greater than that of control seedlings for most treatments. Differences in black spruce seedling survival, attributable to formulation, were noted during earlier growing seasons. For seedlings planted 1 year after spring treatment, survival was lower for the liquid hexazinone treatment and higher for both granular $(2 \mathrm{~kg}$ ai ha ${ }^{-1}$ ) treatments during the second, third, and fourth growing seasons after planting. Generally, survival did not differ for the two granular treatments. During the fourth GSAP, lower survival was achieved with PRONONE 5G.

Five years after planting, significant differences in growth due to formulation were not observed after fall treatment (Fig. 1). Over the five-year seedling growth period, a number of significant growth differences, attributable to formulation, were observed for both sets of seedlings planted after spring treatment. In all instances, greater growth was achieved with the liquid formulation. Significant differences (i.e. orthogonal contrasts of liquid hexazinone vs. granular hexazinone, $2 \mathrm{~kg}$ ai ha ${ }^{-1}$ ) included: (1) stem diameter, three through five growing seasons after planting (GSAP) for seedlings planted one month after spring treatment; (2) height, three through five GSAP for seedlings planted one year after spring treatment; and (3) stem diameter, during the third GSAP for seedlings planted one year after spring treatment. Differences in growth, attributable to a difference in percent $(\%)$ active ingredient (PRONONE 5G vs. 10G, $2 \mathrm{~kg}$ ai ha $^{-1}$ ), were almost nonexistant. The only observed difference was associated with height $(P=0.0001)$, during the fifth growing season, for seedlings planted one year after spring treatment. Total height for the PRONONE 5G treatment was less than that for the PRONONE $10 \mathrm{G}$ treatment (Fig. 2).

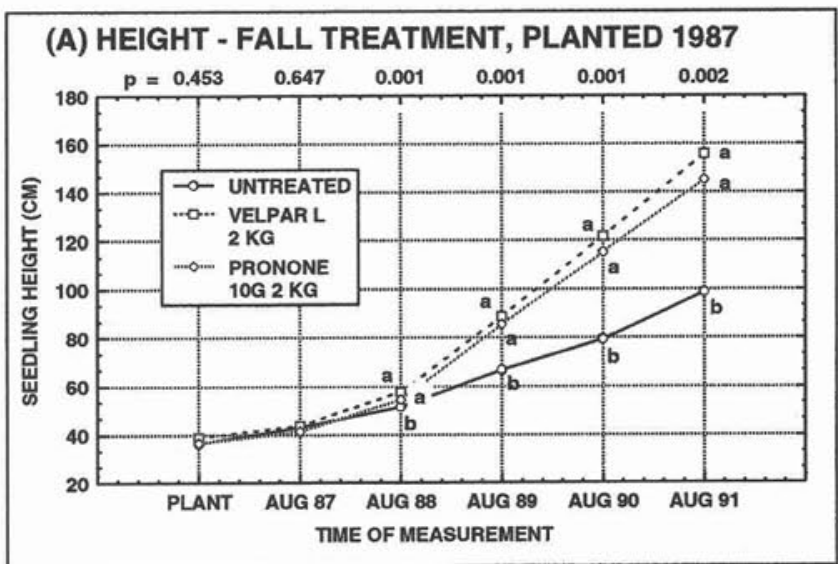

(B) STEM DIAMETER - FALL TRTM., PLANTED 1987

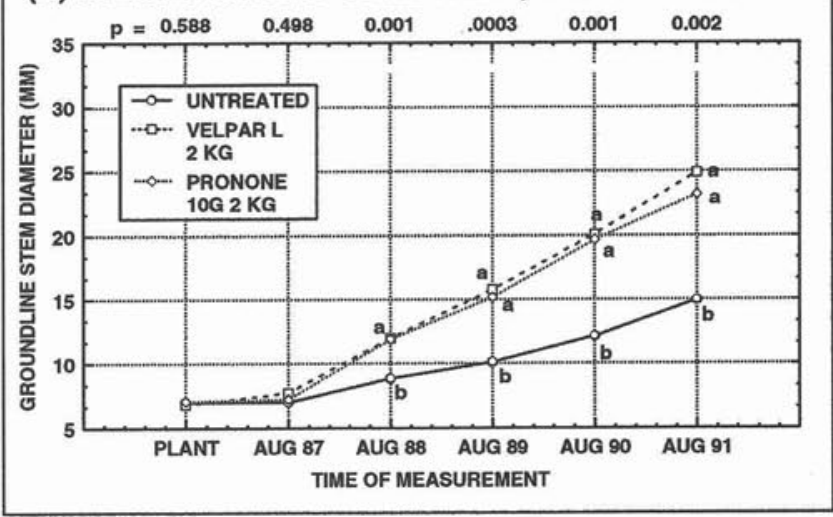

Figure 1. Increases in black spruce seedling height and groundline diameter (GLD) over time in response to fall site preparation with liquid and granular hexazinone. All bareroot seedlings were planted in June 1987, approximately nine months after hexazinone treatment. 


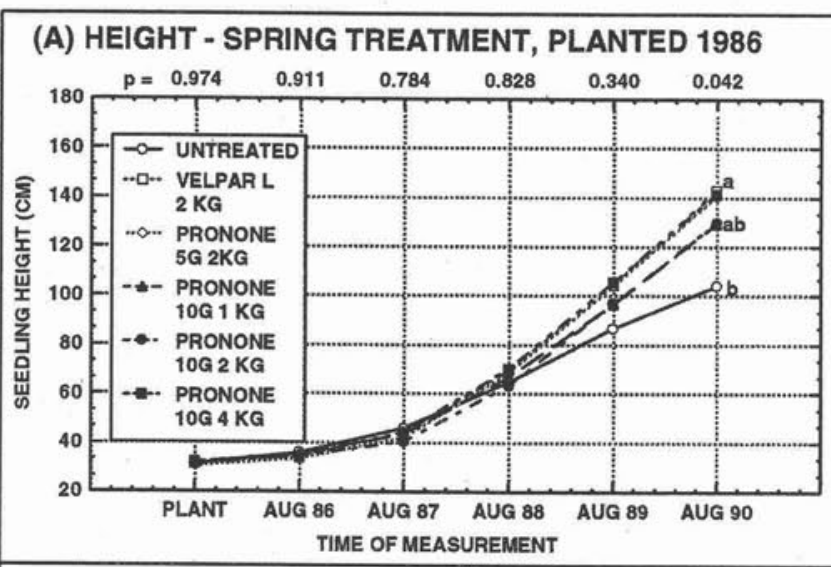

(C) STEM DIAMETER - SPRING TRTM, PLANTED 1986

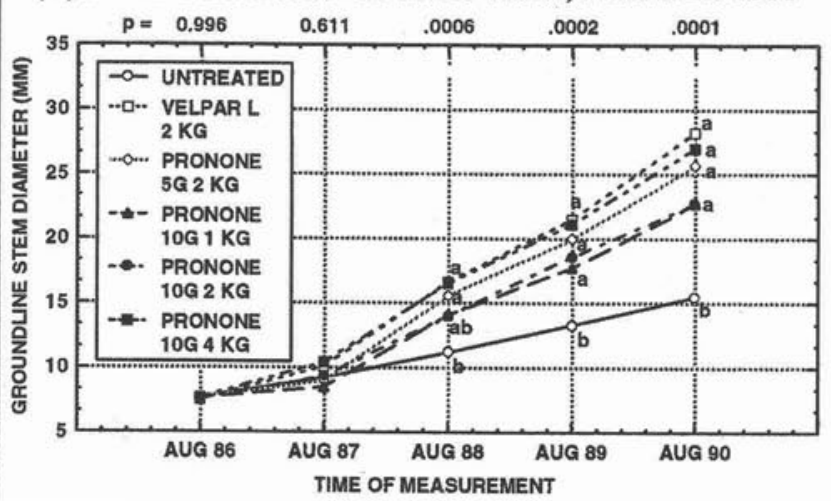

(B) HEIGHT - SPRING TREATMENT, PLANTED 1987

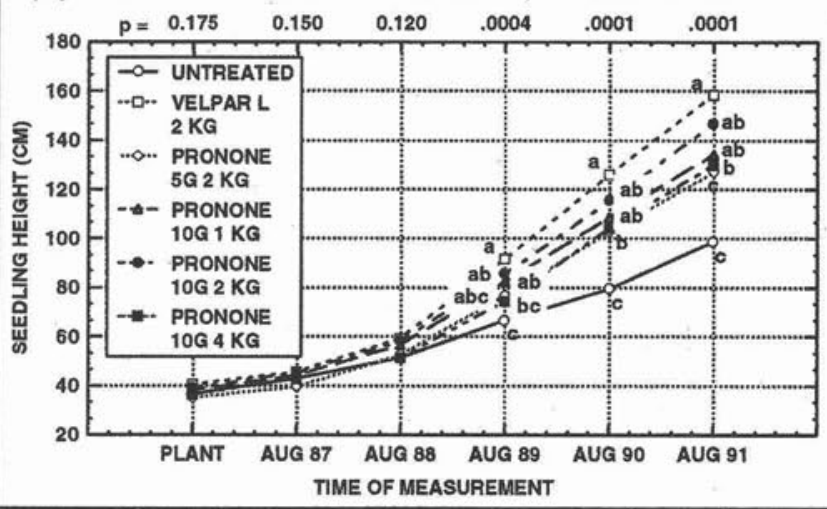

(D) STEM DIAMETER - SPRING TRTM., PLANTED 1987

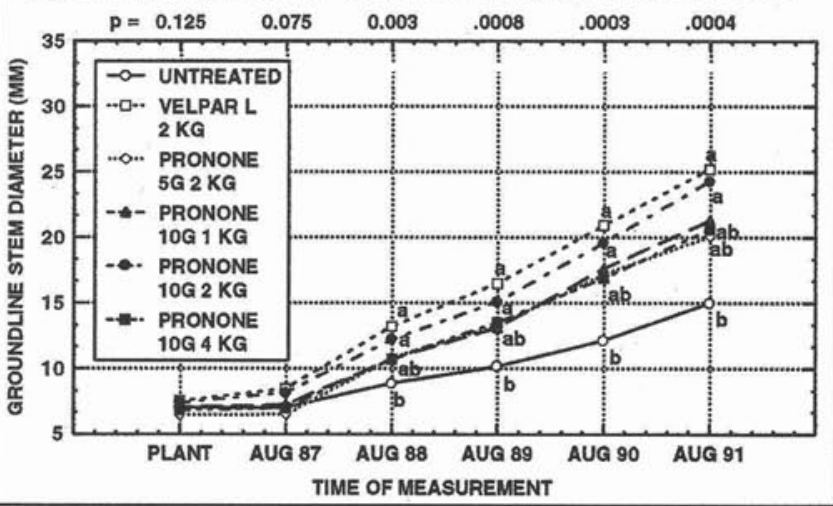

Figure 2. Increases in black spruce seedling height and groundline diameter (GLD) over time in response to spring site preparation with liquid and granular hexazinone. Bareroot seedlings were planted in June 1986 and in June 1987, approximately one month or one year after herbicide treatment.

Initial black spruce seedling height and groundline diameter (GLD) did not differ $(P=0.125$ to 0.996$)$ significantly among treatments (Figs. 1 and 2). Significant diameter increases over control seedlings were first observed 2 GSAP $(P=0.003)$ for seedlings planted approximately one year after spring hexazinone treatment and three $\operatorname{GSAP}(P=0.0006)$ for seedlings planted approximately one month after spring treatment. Significant height increases over control seedlings were first observed three GSAP $(P=0.0004)$ for seedlings planted one year after spring treatment and five GSAP $(P=0.042)$ for seedlings planted one month after spring treatment. Significant diameter $(P=0.001)$ and height $(P=0.001)$ increases over control seedlings were first observed two GSAP for fall hexazinone treatments.

Fifth-year seedling growth was significantly correlated with raspberry competition, decreasing as competition increased. All relationships were somewhat curvilinear, and subsequent natural $\log$ transformations of growth data generally resulted in better correlations. Linear regressions relating fifthyear black spruce seedling height or stem diameter to 1990 or 1991 raspberry cover or height explained up to $76 \%$ of the variation in height and $74 \%$ of the variation in stem diameter, and the best relationships were generally with raspberry height (Figs. 3-5). An analysis of covariance (ANCOVA) for possible treatment differences due to planting time (Fig. 3B) revealed a significant difference at $P=0.023$. However, additional testing for homogeneity of variances and parallelism of regression lines, revealed no significant differences in variances or slopes.
Similar ANCOVA's for possible treatment differences due to treatment time (Fig. 4) and formulation (Fig. 5) revealed no significant treatment differences.

\section{Discussion}

Reducing raspberry competition with hexazinone enhanced black spruce survival and growth for bareroot seedlings planted approximately one year after spring hexazinone treatment. Reducing raspberry competition with fall hexazinone treatment also enhanced black spruce seedling survival and growth. Wood et al. (1989) reported significant growth increases for bareroot, black spruce seedlings planted at varying time intervals after site preparation with liquid hexazinone (VELPAR L). Wood et al. (1990) also reported significant black spruce growth increases for seedlings planted in the spring after winter site preparation with PRONONE.

Sufficient rainfall was received in June $1986(53 \mathrm{~mm})$ for the release of nearly all hexazinone from PRONONE granules into the soil. Feng et al. $(1988,1989)$ studied the release of hexazinone from PRONONE 10G granules under both laboratory and field conditions. They concluded that $51.0 \mathrm{~mm}$ of simulated rain resulted in $91.5 \%$ release, and under field conditions (northern Alberta), 90.6\% release resulted after 11.7 $\mathrm{mm}$ of rainfall. Release was virtually complete after $26.2 \mathrm{~mm}$ of cumulative rainfall.

Delaying planting one year generally improved survival and growth of seedlings planted into spring hexazinone treatments. Improved survival and growth resulted from lower 

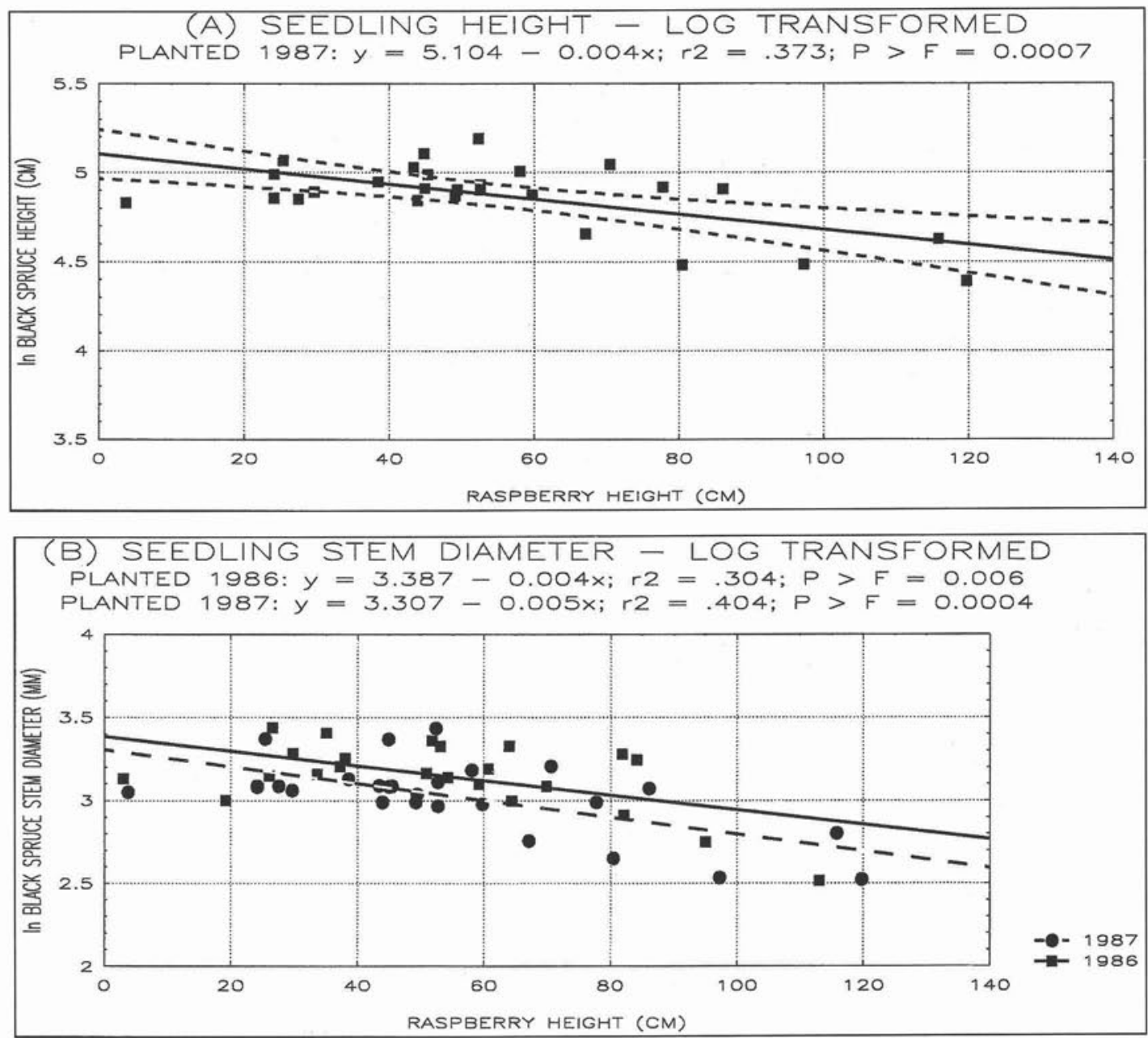

Figure 3. Relationship of fifth-year black spruce seedling height and groundline diameter (GLD) to raspberry height in August 1990 (planted June 1986) or in August 1991 (planted June 1987) after site preparation with hexazinone in May 1986. Model includes control and all hexazinone treatments, and permits evaluation of possible treatment differences related to planting time.

hexazinone exposure. Research has determined that once in the soil, hexazinone persists up to one year after application (Feng and Feng 1988; Prasad and Feng 1990; Roy et al. 1989). In New Brunswick, at a nearby site characterized by loam soils ( $47.9 \%$ sand, $32.5 \%$ silt, and $19.6 \%$ clay), aerially treated with $3.8 \mathrm{~kg}$ ai ha- ${ }^{-1}$ hexazinone (VELPAR L), Feng and Feng (1988) found $0.05 \mathrm{~kg} \mathrm{ha}^{-1}$ hexazinone at $15-30 \mathrm{~cm}$ soil depth after 361 days, and reported DT ${ }_{90}=319$ days. No residues were found 453 and 537 days after application. In northern Ontario, Roy et al. (1989) reported slightly higher residues for a finer-textured clay soil after one year. Approximately $13.5 \%$ of original hexazinone residues remained 365 days after initial soil treatment at $4 \mathrm{~kg}$ ai ha ${ }^{-1}$.

Based upon this estimate, one might expect residues ranging from 0.2 to $0.4 \mathrm{~kg} \mathrm{ai} \mathrm{ha}^{-1}$ after one year at the present New Brunswick site, which is characterized by finer-textured soils (mean silt and clay content $=44.3$ and $26.0 \%$, respectively) than those studied by Feng and Feng (1988). For the $4 \mathrm{~kg}$ ai $\mathrm{ha}^{-1}$ treatment, sufficient residues evidently remained after one year to reduce seedling survival, since seedlings planted into this treatment one year after site preparation with hexazinone continued to exhibit lower survival than control seedlings.

At a third nearby New Brunswick site (mean silt and clay content $=42.7$ and $25.8 \%$, respectively), no difference in survival among treatments was observed for containerized (multipot) black spruce seedlings planted 2 or 14 months after site preparation with liquid and dry-flowable hexazinone formulations (Reynolds and Roden 1995a). Both hexazinone formulations were applied in June 1987.

In Ontario, for boreal soils with high clay and organic matter content, Wood et al. (1989) reported that both bareroot and containerized black spruce seedlings could be safely planted four weeks after site preparation with hexazinone at dosages up to $2 \mathrm{~kg}$ ai ha ${ }^{-1}$. At higher dosages (i.e. up to $4 \mathrm{~kg}$ ai ha ${ }^{-1}$ ), seedling damage was avoided only by delaying planting by about one year.

Normally, soil adsorption of hexazinone increases with increased clay or organic matter content, making it less available for absorption by seedlings. At high hexazinone rates, this adsorptive capacity may be saturated, making hexazinone residues more available for absorption by seedlings. The high clay content of the Ontario soil may be the explanation as to why bareroot 

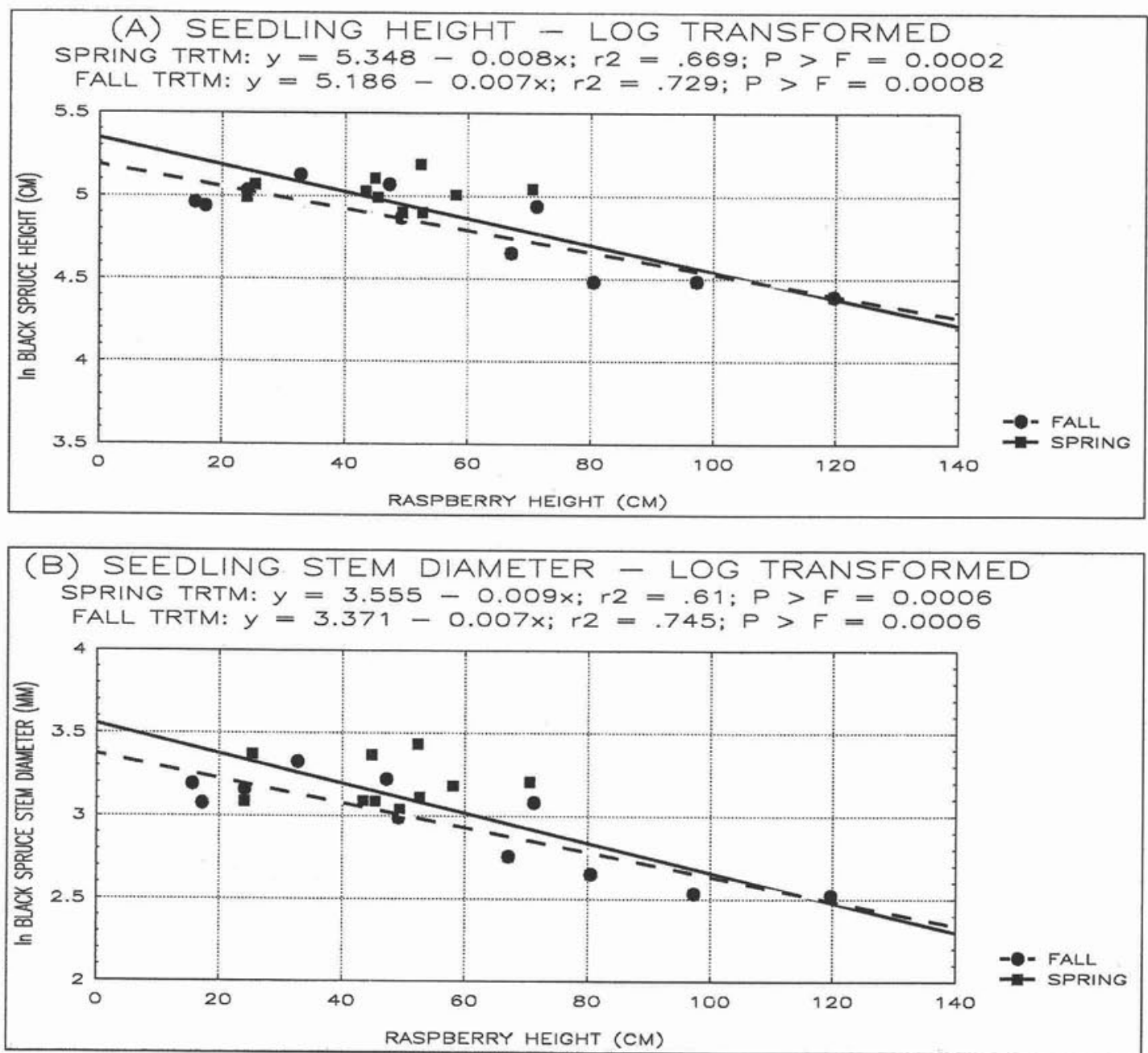

Figure 4. Relationship of fifth-year black spruce seedling height and groundline diameter (GLD) to raspberry height in August 1991 (all seedlings planted in June 1987) after site preparation with hexazinone in May 1986 and in September 1986. Model includes control, granular (PRONONE 10G, $2 \mathrm{~kg}$ ai ha-1), and liquid (VELPAR L, $2 \mathrm{~kg}^{-1}$ ai ha $^{-1}$ ) treatments, and permits evaluation of possible treatment differences related to spring vs. fall herbicide application.

seedlings could be safely planted one month after hexazinone treatment, whereas they could not in New Brunswick. However, at $4 \mathrm{~kg}_{\text {ai ha- }}{ }^{-1}$, the adsorptive capacity of the Ontario soil appeared to be exceeded. In New Brunswick, a one month difference in planting times for bareroot and multipot stock allowed for a longer degradation period in soils of nearly identical silt and clay content, but residues were likely still quite high two months after treatment. Therefore, we speculate that poor survival of bareroot seedlings may have also been caused by greater exposure of their roots to hexazinone residues than that experienced by multipot seedlings. Presumably, bareroot seedlings were more vulnerable to these residues when first planted, since their root systems were more disturbed than multipot seedlings. Collectively, the New Brunswick and Ontario results suggest that soil texture, organic matter content, stock type, and planting time all play roles in determining black spruce seedling survival, and that the use of containerized seedlings may help reduce seedling mortality due to hexazinone exposure.

Several survival differences, attributable to formulation (i.e. liquid vs. granular, $2 \mathrm{~kg}$ ai $\mathrm{ha}^{-1}$ ), were observed over the five-year observation period. For seedlings planted 1 year after spring treatment with hexazinone, lowest survival was achieved with the liquid formulation. Wood et al. (1990) reported that survival of bareroot and containerized black spruce planted in the spring following winter site preparation with PRONONE was not adversely affected by application rates up to $6 \mathrm{~kg}$ ai $\mathrm{ha}^{-1}$, whereas both types of seedlings were damaged by dosages of more than $2 \mathrm{~kg}$ ai ha ${ }^{-1}$ of VELPAR L when planted within four weeks of a spring herbicide treatment. Both hexazinone applications occurred at nearby sites within northern Ontario's Clay Belt Region. They speculated that this discrepancy may have resulted from differences in the formulations used, and that hexazinone released from PRONONE granules may have entered the soil more slowly than hexazinone contained in the liquid formulation. Despite differences in timing for the two Ontario applications, the present results seem to confirm that there is a difference in black spruce seedling survival associated with the use of the two formulations.

Although significant differences in raspberry control affected by formulation were not observed, Minogue et al. (1988) reported that treatment with liquid hexazinone resulted in better 

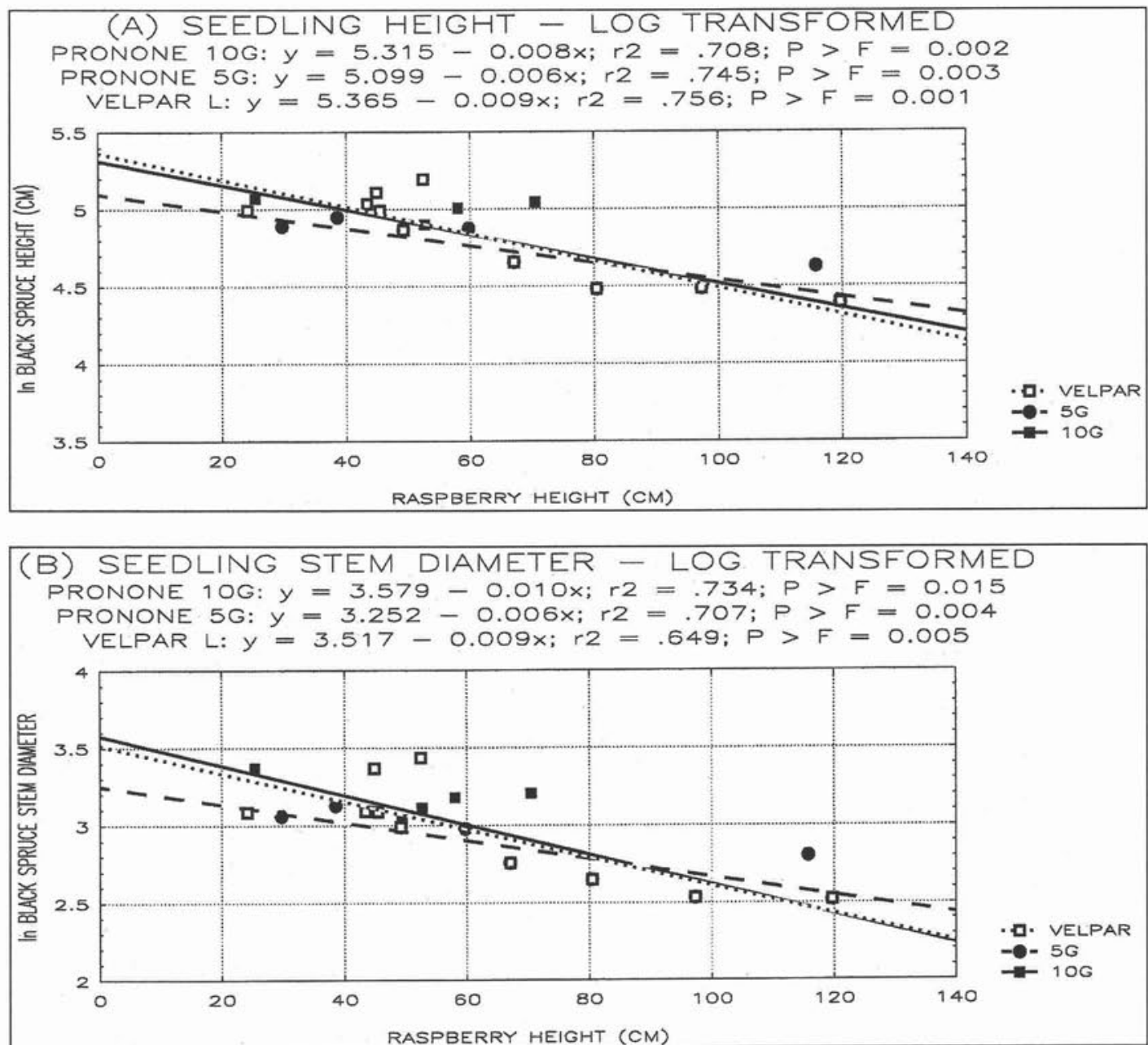

Figure 5. Relationship of fifth-year black spruce seedling height and groundline diameter (GLD) to raspberry height in August 1991 (all seedlings planted in June 1987) after site preparation with hexazinone in May 1986. Model includes

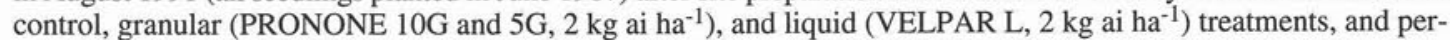
mits evaluation of possible treatment differences related to hexazinone formulation.

hardwood control and loblolly pine growth than treatment with granular hexazinone, for soils with less than $60 \%$ sand content. Mean sand content for soils in this study was approximately $30 \%$, and may explain why maximum growth was observed with the liquid formulation.

In this study, bareroot black spruce seedlings planted after spring hexazinone treatment responded first with diameter growth increases over controls. These increases occurred during the second growing season after planting (GSAP) for seedlings planted one year after treatment and during the third GSAP for seedlings planted one month after treatment. Height growth increases over controls were delayed for an additional year for seedlings planted one year after treatment and two years for those planted one month after treatment. Elsewhere in New Brunswick, Reynolds and Roden (1995b) observed a similar response for multipot, black spruce seedlings planted two months after hexazinone treatment. Diameter increases over control seedlings were observed two years sooner than height increases, but occurred during the first GSAP. We speculate that this discrepancy in response time for containerized vs. bareroot seedlings is best accounted for by differences in root exposure to hexazinone residues for the two stock types at the time of planting. Since the roots of bareroot seedlings were probably more exposed to hexazinone residues at planting, they responded more slowly to newly available site resources than multipot seedlings whose roots were probably less exposed to residues at planting.

Spring treatment with PRONONE 10G $\left(2 \mathrm{~kg}\right.$ ai ha $\left.{ }^{-1}\right)$, with planting delayed by approximately one year, provided the best treatment to achieve both optimal black spruce seedling survival and growth during the establishment phase of the plantation. Poor survival (i.e. less than control seedlings) was observed for seedlings planted one month after spring treatment. Better survival was most often observed with the granular formulations than with liquid hexazinone, for seedlings planted approximately 1 year after hexazinone treatments. Since fifth-year survival and growth for the $10 \%$ granular and liquid formulations did not differ, operational needs should be considered when selecting the best treatment. Operationally, a typical aircraft can treat more hectares per load with the PRONONE 10G formulation, because this formulation does not require a water carrier. These survival and/or growth 
increases over that of untreated seedlings are comparable with those reported by other researchers who have studied spruce growth response following hexazinone site preparation for herbaceous vegetation control (Pitt et al. 1988; Sutton 1986; Wood et al. 1989). They are generally greater than those reported for spruce using other vegetation management techniques such as manual cutting, prescribed burning, and certain types of scarification (Baskerville 1961; LeBarron 1948; McMinn 1981).

\section{Acknowledgements}

We thank United Agri Products and DuPont Canada, Inc. for financial support for this research. We also thank Forestry Canada, Maritimes Region and J.D. Irving, Ltd. for logistical support. We thank Mssrs. Ray Wellman, Jamie Corcoran, Rudy van Horsigh, David Wellman, Clair Langlois, Pat Marceau, Irwin Schmidt, Frank Huston, Alain Ouellette, Pierre Patenaude, and Gaetan Pelletier for their assistance in initiating and sustaining this research. Finally, we thank Mssrs. Roy Sutton, Fred von Althen, Bob Campbell, and Stephen Horsley for reviewing the manuscript.

\section{References}

Baskerville, G.L. 1961. Response of young fir and spruce to release from shrub competition. Canada Department of Forestry, Forest Research Division Technical Note No. 98, Ottawa, Canada. 14 p.

Campbell, R.A. 1990. Herbicide use for forest management in Canada: Where we are and where we are going? The Forestry Chronicle 66: 355-360.

Campbell, R.A. 1991. Silvicultural herbicides in Canada: registration status and research needs. The Forestry Chronicle 66: 355-360. Feng, J. and C. Feng. 1988. Determination of hexazinone residues and their fate in a New Brunswick forest. Canadian Forestry Service, Forest Pest Management Institute Information Report FPM-X-81. 20 p.

Feng, J.C., C.C. Feng and S. S. Sidhu. 1989. Determination of hexazinone residue and its release from a granular formulation under forest conditions. Can. J. For. Res. 19: 378-381.

Feng, J.C., V.Stornes, and R. Rogers. 1988. Release of hexazinone from PRONONE 10G granules exposed to simulated rainfall under laboratory conditions. J. Environ. Sci. Health B23(3): 267-278.

LeBarron, R.K. 1948. Silvicultural management of black spruce in Minnesota. USDA Circular No. 791. Washington, DC. 60 p.

McMinn, R.G. 1981. Ecology of site preparation to improve performance of planted white spruce in northern latitudes, Pp. 25-32. In: M. Murray (Ed.) Proceedings of a Third International Workshop on Forest Regeneration at High Latitudes: Experiences from Northern British Columbia. USDA, Forest Service Miscellaneous Report No. 82-1. Fairbanks, Alaska and Portland, Oregon.

Minogue, P.J., B.R. Zutter and D.H. Gjerstad. 1988. Soil factors and efficacy of hexazinone formulations for loblolly pine (Pinus taeda) release. Weed Sci. 36: 399-405.
Pitt, D.G., P.E. Reynolds and M.J. Roden. 1988. Growth and tolerance of white spruce after site preparation with liquid hexazinone. Proceedings of the Northeastern Weed Science Society, Supplement 42: 41-47.

Prasad, R. and J.C. Feng. 1990. Spotgun-applied hexazinone: release of red pine (Pinus resinosa) from quaking aspen (Populus tremuloides) competitition and residue persistence in soil. Weed Tech. 4: 371-375.

Reynolds, P.E. 1988. Prognosis for future herbicide use in Canada. Canadian Forest Industries Magazine 108(2): 35-42.

Reynolds, P.E. and M.J. Roden. 1991a. Effect of various chemical site prep treatments on free-to-grow status of black spruce. Proceedings of the Northeastern Weed Science Society 45: 215-222. Reynolds, P.E. and M.J. Roden. 1991b. Black spruce mortality three or four years after site prep with sulfometuron, metsulfuron, and hexazinone. Proceedings of the Northeastern Weed Science Society 45: 230-236.

Reynolds, P.E. and M.J. Roden. 1995a. Short-term performance of two hexazinone formulations: efficacy, seedling survival and growth. The Forestry Chronicle 71: 228-232.

Reynolds, P.E. and M.J. Roden. 1995b. Growth of multipot black spruce seedlings planted after site preparation with liquid and dryflowable hexazinone. North. J. Appl. For. 12(2): 75-79.

Reynolds, P.E., D.G. Pitt and M.J. Roden. 1988. Weed efficacy and crop tolerance after site prep with liquid and granular hexazinone formulations. Proceedings of the Northeastern Weed Science Society, Supplement 42: 74-78.

Reynolds, P.E., D.G. Pitt and M.J. Roden. 1989a. Herbicide efficacy and crop tolerance after fall soil treatment with liquid and granular hexazinone. Proceedings of the Northeastern Weed Science Society, Supplement 43: 30-36.

Reynolds, P.E., D.G. Pitt and M.J. Roden. 1989b. Crop tolerance after spring soil treatment with hexazinone, sulfometuron-methyl and metsulfuron-methyl. Proceedings of the Northeastern Weed Science Society, Supplement 43: 51-57.

Roy, D.N., S.K. Konar, D.A. Charles, J.C. Feng, R. Prasad and R.A. Campbell. 1989. Determination of persistence, movement, and degradation of hexazinone in selected Canadian boreal forest soils. J. Agric. Food Chem. 37: 443-447.

Sokal, R.R. and F.J. Rohlf. 1981. Biometry. W.H. Freeman and Company, New York.

Sutton, R.F. 1986. Hexazinone gridballs ${ }^{\mathrm{TM}}$ applied with concurrent underplanting of white spruce in boreal mixedwoods: 7-year results. The Forestry Chronicle 62: 226-232.

Wood, J.E., R.A. Campbell and F.W. Curtis. 1989. Black spruce outplantings in boreal Ontario: chemical site preparation with hexazinone. Forestry Canada, Ontario Region Information Report O-X398. 28 p.

Wood, J.E., F.W. von Althen and R.A. Campbell. 1990. Black spruce outplant performance: effect of winter application of hexazinone on shear-bladed sites in boreal Ontario. Can. J. For. Res. 20: 1541-1548. 